tained interest in them. In the past few decades rather more research has been carried out, but this may reflect nothing more than the overall increase in the number of scientists.

More recently silicoflagellates and ebridians have been found to have some value in correlating marine oceanic sediments and it is to be expected that there will be some increase in interest following from this. This index may well stimulate yet more interest by bringing together, in compact form, so many scattered data and by clearly showing the scope and content of the groups. The authors are right to emphasize that the literature covered by their book is widely scattered and often obscurely published. They have been very diligent and thorough in bringing the essentials together in one volume.

There are 23 pages devoted to a historical account of research on silicoflagellates and ebridians and there is a review of the nomenclatural history of the groups. There follows an index of genera and lower taxa, including both valid and invalid names, which contains over 1,000 entries.

In the next section, 126 pages repeat the first descriptions of the valid taxa, numbering about 400 . These are given in their original language, presumably with the object of saving the new researcher the trouble of going to the original literature. This service is supported by 106 pages of figures repeating the illustrations that accompanied the original descriptions. The book ends with a list of references; it is not a bibliography and only those publications mentioned in the text are included.

The book can be recommended for its excellent production and for its well organized and comprehensive data. It is likely to encourage more work on these groups and will be a useful starting point for further rescarch and a useful reference book for the shelves of planktonologists and micropalaeontologists.

Charles Downie

\section{PROCESSES OF PLANT EVOLUTION}

Plant Variation and Evolution

By D. Briggs and S. M. Walters. (World University Library.) Pp. 256. (Weidenfeld and Nicolson: London, August 1969.) $35 s$ boards; $18 s$ paper.

So many of the problems that faced the early workers on variations in plants and animals are easily understandable to us today. Without the benefit of this hindsight, we would find these problems, which confused and bothered eminent minds such as Pearson, Darwin and Linnaeus, very frustrating. Now that we understand principles such as genotype and phenotype, population differentiation, phenotypic plasticity and apomixis, the causes of variation seem almost self evident and sometimes rather ordinary.

Briggs and Walters have therefore decided to go back to the stage when everything was not clear, and to trace in a simple manner the evidence that has contributed to our understanding. But they have not set out to writo a purely historical account, rather an authoritative introduction to the processes of evolution in plants. The authors are well fitted to this task; their great delight in their subject and their enormous width of experience is apparent in every part of the book.

They begin by showing patterns of variation as the untutored person would have seen them, through the work of early workers such as de Vries, Pearson and Ludwig. 'This Baconian approach is maddening, because the reader is left wondering what he should induce from it all. But perhaps this is just what the authors intended. Subsequently, they meticulously piece together the work of Johannsen, Kerner and Mendel, and of today's investigators to show how the variability can be understood and explained.

The process of evolution is treated in the same way. But the ideas about evolution that existed before Darwin are treated only briefly and we are quickly brought to the present and to the work that has shown the many. sided nature of plant evolution and species formation. The wealth of examples (with references) is delightful: I wonder how many people are familiar with the seed coat polymorphism of Spergula arvensis in Europc; the differentiation of leaf shape of Scalesia in the Galapagos; the degree of isolation between adjacent populations of Elymus glaucus in the Sierra Nevada; or the changes occurring in hybrid populations of Helianthus.

On occasions, the authors sometimes let their own intellectual standards run away with them. I shall never be able to think of a spocics as a hologamodeme, and I cannot see the value to the book of the statistical methods they give. But their style is delightful and their clarity and enthusiasm overwhelming. There are excellent diagrams and coloured photographs that set a very high standard indeed. In the last chapter, means by which the amateur can himself examine underlying causes of variation are suggested. There can be few people who will fail to be delighted by this book. A. D. Bradshatw

\section{TRADITIONAL SYSTEMATICS}

\section{Fossil Plants of the Carboniferous Rocks of Great Britain}

(Second Section.) By Robert Crookall. (Memoirs of the Geological Survey of Great Britain. Palaeontology, Vol. 4, Part 5.) Pp. xxi-xxviii + 573-792 + plates $107-150$. (HMSO: London, June 1969.) $168 s$.

THIs latest part of Crookall's systematic cataloguo of British Carboniferous plants is devoted to the horsetails (Sphenophytina or, to use the outmoded classification adhered to in this work, Articulatales). The four previously published parts have covered Alethopterideae together with tree-fern stems (Part 1), Neuropterideae (Part 2) and lycopods (Parts 3 and 4).

About one hundred taxa (genera, species and forms) are described and illustrated. Each description is preceded, as is traditional, by synonymy, that is, references to earlier descriptions and records which sometimes here run to well over a hundred. Following the concise description is a scction headed "Remarks" consisting largely of taxonomic and comparative notes with brief references to possible identity with organs of different kinds. Finally, a very brief survey is given of the geological and geographical distribution within Britain. The work is illustrated by forty-four collotype plates of reason. able quality and sixty-five text-figures most of which are rather coarse screen half-tone reproductions of previously published figures and therefore of indifferent quality. For each species or form described there is at least one plate figure, and invariably included is an illustration of the type material often, and quite unavoidably, of course, by reproduction of tho original author's figure.

The work serves as a documonted record of the fossil taxa it describes, these taxa being based on the dismembered and compressed remains of the plants which constituted the succession of Carboniferous floras. Such a record is useful for those concerned with the task of applying acceptable names to specimens of this kind, but beyond this it fulfils little purpose. The value of being able to give the name Pinnularia columnaris to portions of root systems which may have belonged to any one of many different kinds of plants seems small indeed. Although this particular example is an extreme one, it illustrates the scientific weakness in the traditional, essentially static approach to fossil plants. If progress is to be made in the meaningful taxonomy of Carbonifer. ous plant compressions, much more work must be under. taken in ordor to correlate plant organs of different kinds or preserved in different ways and to gain some better understanding of the range of morphological variation occurring within individual plants and species. Such 